\title{
Chromosome Pairing in Interspecific Hybrids of Tagetes patula and T. erecta
}

\author{
Jia F. Chen and Yue J. Lin \\ Department of Biological Sciences, St. John's University, \\ Jamaica, New York 11439, U.S.A.
}

Received March 18, 1981

Tagetes is a genus of the subfamily Heleniae of the ligulate Compositae. Diploid $T$. erecta $(2 \mathrm{n}=24)$ and tetraploid $T$. patula $(2 \mathrm{n}=48)$ have been grown as ornamental plants. Eyster (1941) suggested that $T$. patula was derived from chromosome doubling of $T$. erecta, but Bolz $(1961)$ and Towner $(1961,1962)$ suggested that $T$. patula was an amphidiploid from $T$. erecta and $T$. tenuifolia $(2 n=24)$ or species closely related to them. The genomes of the three species were designated as $\mathrm{A}_{1}$ for $T$. erecta, $\mathrm{B}_{1}$ for $T$. tenuifolia, and $\mathrm{A}_{\mathrm{p}} \mathrm{B}_{\mathrm{p}}$ for $T$. patula by Towner (1961). The 24 chromosomes of $T$. erecta $\mathrm{cv}$. Papaya Crush are mostly present in the form of 12 bivalents at meiosis. Univalents and quadrivalent were also observed in some cells (Chen and Lin 1981). The 48 chromosomes of $T$. patula are most frequently present as 24 bivalents. Multivalents were seen in $50.84 \%$ of the pollen mother cells (PMC) examined (Chen and Lin 1981). Analysis of chromosome pairing in the hybrids between $T$. patula and $T$. erecta could help explain the origin of $T$. patula. Bolz (1961), Jalil, Khoshoo and Pal (1974) reported that the 36 chromosomes of the hybrids between $T$. patula and $T$. erecta were mostly presentas 12 bivalents and 12 univalents at meiosis. Trivalents were infrequently noted (Eresen 1966, Jalil et al. 1974). No other types of chromosome pairing in the hybrids have been reported. In this paper, we report 15 types of chromosome pairing in the hybrids in addition to $12 \mathrm{II}+12 \mathrm{I}$. Pollen viability, seed fertility and meiotic irregularities observed in the hybrids are also reported. The origin of $T$. patula is considered.

\section{Material and methods}

The seeds of the three cultivars of interspecific hybrids between $T$. patula and $T$. erecta used in this study were obtained from W. Atlee Burpee Co. of Warminster, PA, USA. They were Gold Nugget, Orange Nugget, and Red and Gold Hybrid. PMC were used to study the chromosome pairing and the methods of preparing slides of PMC and measuring pollen viability have been described (Chen and Lin 1981).

Roman numerals are used in this report to represent valency, for example, I represents univalent, II represents bivalent, and so on. Standard errors were calculated for mean values. 


\section{Results}

A wide variation of meiotic pairing occurred in the hybrids with various combinations of univalents (Figs. 1-3), bivalents (Figs. 1-3), trivalents (Fig. 2), and
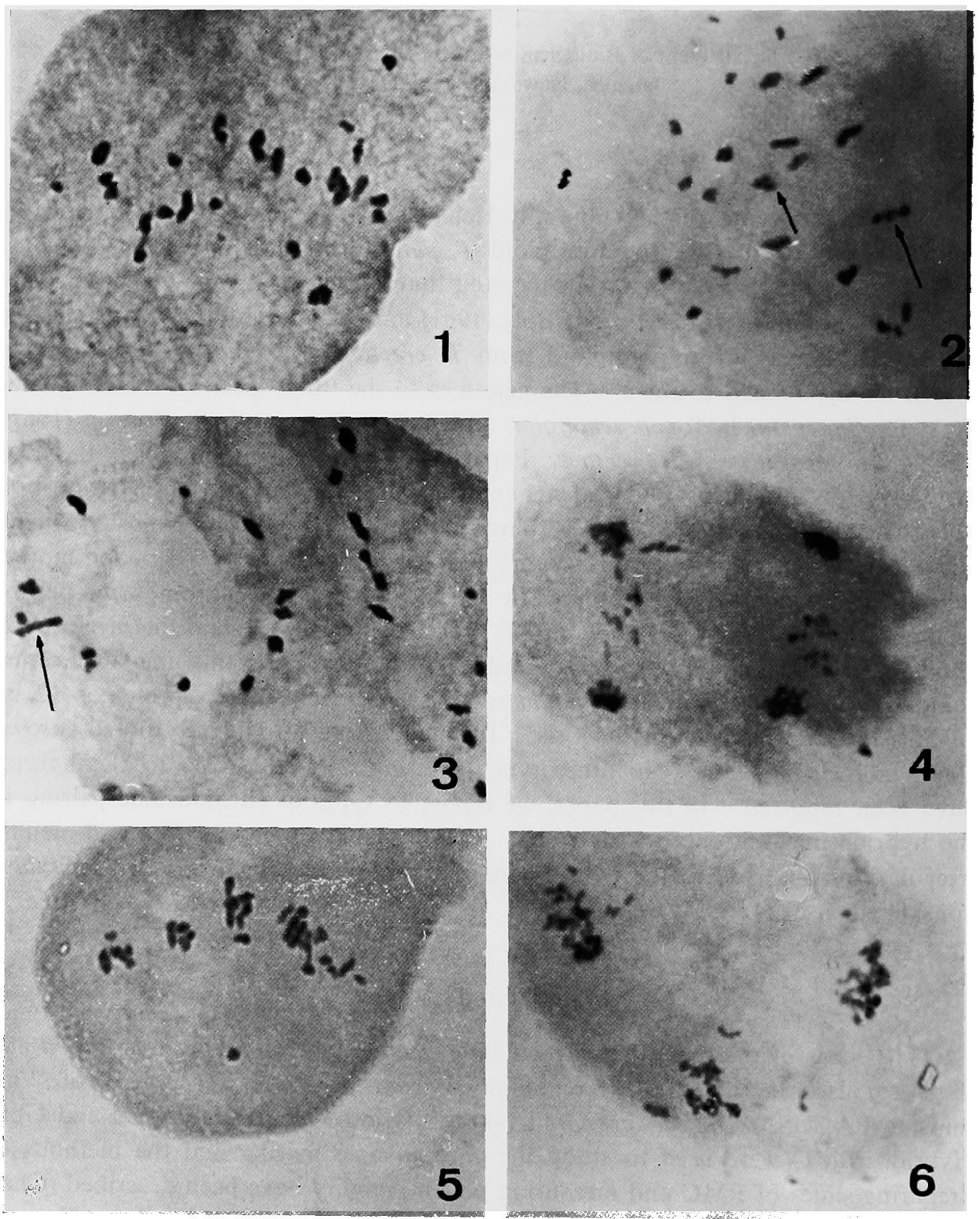

Figs. 1-6. Meiosis in interspecific hybrids of $T$. patula and $T$. erecta. $\quad \times 1280 . \quad 1,12 \mathrm{II}+12 \mathrm{I}$ at MI in Red and Gold Hydbid. 2, 9 II +12 I +2 III (arrows) in Red and Gold Hybrid. 3, $10 \mathrm{II}+$ 12 I + 1 IV (arrow) in Red and Gold Hybrid. 4, a telophase II cell with many laggards in Orange Nugget. 5, a univalent lying away from the equatorial plane at MI in Red and Gold Hybrid. 6, three groups of chromosomes at TI in Orange Nugget. 
quadrivalent (Fig. 3) (Table 1). Sixteen types of chromosome pairing were observed in 72 metaphase I (MI) cells and their frequencies are in Table 1. The $12 \mathrm{II}+$ 12 I association (Fig. 1) was the most frequent (30.56\%, Table 1). An analysis of chromosome pairing revealed the presence of 6-14 univalents (mean $10.97 \pm$ 0.20 ), $8-15$ bivlants (mean 11.22 \pm 0.15 ), $0-3$ trivalents (mean $0.75 \pm 0.10$ ) and $0-1$ quadrivalent (mean $0.08 \pm 0.00$ ) per cell (Table 2). A maximum of 15 bivalents occurred in a cell (Tables 1 and 2). About a half of the PMC (56.95\%) analyzed con-

Table 1. Sixteen configurations of chromosome pairing at MI and their frequencies in interspecific hydrids of Tagestes patula and $T$. erecta

\begin{tabular}{|c|c|c|c|c|c|}
\hline \multirow{2}{*}{$\begin{array}{l}\text { Chromosome } \\
\text { pairing }\end{array}$} & \multicolumn{3}{|c|}{ Number of cells } & \multirow[b]{2}{*}{ Total } & \multirow{2}{*}{$\begin{array}{l}\text { Frequency } \\
(\%)\end{array}$} \\
\hline & $\begin{array}{l}\text { Red and Gold } \\
\text { Hybrid }\end{array}$ & $\begin{array}{c}\text { Gold } \\
\text { Nuggest }\end{array}$ & $\begin{array}{l}\text { Orange } \\
\text { Nuggest }\end{array}$ & & \\
\hline $12 \mathrm{II}+12 \mathrm{I}$ & 18 & 2 & 2 & 22 & 30.56 \\
\hline $11 I I+11 I+1 I I I$ & 7 & 5 & 0 & 12 & 16.67 \\
\hline $10 \mathrm{II}+10 \mathrm{I}+2 \mathrm{III}$ & 2 & 4 & 1 & 7 & 9.72 \\
\hline $10 \mathrm{II}+13 \mathrm{I}+1 \mathrm{III}$ & 5 & 0 & 1 & 6 & 8.33 \\
\hline $12 \mathrm{II}+9 \mathrm{I}+1 \mathrm{III}$ & 5 & 0 & 0 & 5 & 6.94 \\
\hline $13 \mathrm{II}+10 \mathrm{I}$ & 3 & 0 & 1 & 4 & 5.56 \\
\hline $10 \mathrm{II}+12 \mathrm{I}+1 \mathrm{IV}$ & 2 & 0 & 1 & 3 & 4.17 \\
\hline $11 \mathrm{II}+8 \mathrm{I}+2 \mathrm{III}$ & 0 & 1 & 1 & 2 & 2.78 \\
\hline $11 \mathrm{II}+14 \mathrm{I}$ & 2 & 0 & 0 & 2 & 2.78 \\
\hline $9 I I+9 I+3 I I I$ & 1 & 1 & 0 & 2 & 2.78 \\
\hline $14 \mathrm{II}+8 \mathrm{I}$ & 1 & 1 & 0 & 2 & 2.78 \\
\hline $9 \mathrm{II}+12 \mathrm{I}+2 \mathrm{III}$ & 1 & 0 & 0 & 1 & 1.39 \\
\hline $15 I I+6 I$ & 1 & 0 & 0 & 1 & 1.39 \\
\hline $10 \mathrm{II}+6 \mathrm{I}+2 \mathrm{III}+1 \mathrm{IV}$ & 0 & 0 & 1 & 1 & 1.39 \\
\hline $8 \mathrm{II}+10 \mathrm{I}+2 \mathrm{III}+1 \mathrm{IV}$ & 0 & 0 & 1 & 1 & 1.39 \\
\hline $8 \mathrm{II}+13 \mathrm{I}+1 \mathrm{III}+1 \mathrm{IV}$ & 0 & 0 & 1 & 1 & 1.39 \\
\hline Total & & & & 72 & \\
\hline
\end{tabular}

Table 2. Chromosome pairing in $72 \mathrm{MI}$ cells of interspecific hybrids $(2 \mathrm{n}=36)$ of $T$. patula and $T$. erecta

\begin{tabular}{lccccccc}
\hline & \multicolumn{3}{c}{ Chromosome pairing (per cell) } & & \multicolumn{2}{c}{$\%$ PMC having } \\
\cline { 2 - 4 } & I & II & III & IV & & multivalents & univalents \\
\hline Range (no.) & $6-14$ & $8-15$ & $0-3$ & $0-1$ & & 56.95 & 100.00 \\
Mean no. & 10.97 & 11.22 & 0.75 & 0.08 & & \\
Standard error & \pm 0.20 & \pm 0.15 & \pm 0.10 & \pm 0.00 & & & \\
$*$ & 30.84 & 62.34 & 6.25 & 0.92 & & \\
\hline
\end{tabular}

* Percentage of the total number of chromosomes associated in the given configuration per cell. e.g. for III, $0.75 \times 3$ chromosomes $/ 36$ chromosomes $=6.25 \%$.

tained at least one multivalent (Tables 1 and 2). The trivalent appeared as a chain-of-3 (Fig. 2), a ring-and-rod, or a Y. Configurations of quadrivalent included chain-of-4 (Fig. 3) and ring-and-chain. No multivalents involving more than four chromosomes were seen. In Figs. 2 and 3 are cells with 9 II +12 I +2 III and $10 \mathrm{II}+12 \mathrm{I}+1 \mathrm{IV}$, respectively. 
Lagging chromosomes occurred very frequently (Fig. 4, Table 3). The amount of cells with laggards among the three cultivars varied from 82.14 to $90.00 \%$ at MI and MII. The mean value was $83.33 \%$ at MI, $85.57 \%$ at MII and $84.28 \%$ at meiosis (Table 3). Among those cells with laggards, $35.43 \%$ had at least four laggards (Table 3). Very rarely, a cell may have a very large number of laggards (Fig. 4). Occasionally, chromosomes were off the equatorial plane (Fig. 5). Multiple aggregation of chromosomes (Fig. 6) and bridges were occasionally observed. The mean pollen viability of the three cultivars was $13.60 \%$. The fertility of the seeds from Red and Gold Hybrid was $15.00 \%$, but that of both Gold Nugget and Orange Nugget was $0 \%$ (Table 4 ).

Table 3. Meiotic irregularities in interspecific hybrids if Tagetes patula and T. erecta

\begin{tabular}{|c|c|c|c|c|c|c|c|}
\hline \multirow[b]{2}{*}{ Cultivar } & \multicolumn{6}{|c|}{ Lagging } & \multirow{2}{*}{$\begin{array}{c}\text { Bridging } \\
\begin{array}{c}\text { Number } \\
\text { of } \\
\text { Bridges }\end{array}\end{array}$} \\
\hline & $\underset{\text { I }}{\text { Meiosis }}$ & $\begin{array}{l}\text { Meiosis } \\
\text { II }\end{array}$ & $\begin{array}{l}\text { Meiosis I } \\
\text { and } \\
\text { Meiosis II }\end{array}$ & $\begin{array}{l}\text { Total } \\
\text { cells } \\
\text { scored }\end{array}$ & $\begin{array}{l}\text { No. of } \\
\text { laggards }\end{array}$ & $\begin{array}{l}\% \text { cells with } \\
4 \text { or more } \\
\text { laggards }\end{array}$ & \\
\hline $\begin{array}{l}\text { Red and } \\
\text { Gold Hybrid }\end{array}$ & $15 / 17^{*}$ & $27 / 30$ & $42 / 47$ & 47 & $1-6$ & & 1 \\
\hline$\%$ & 88.24 & 90.00 & 89.36 & & & 20.00 & \\
\hline Gold Nugget & $49 / 59$ & $42 / 50$ & $91 / 109$ & 109 & $1-9$ & & $1-4$ \\
\hline$\%$ & 83.05 & 84.00 & 83.49 & & & 34.80 & \\
\hline Orange Nugget & $46 / 56$ & $14 / 17$ & $60 / 73$ & 73 & $1-9$ & & $1-2$ \\
\hline$\%$ & 82.14 & 82.35 & 82.19 & & & 51.50 & \\
\hline Mean & 83.33 & 85.57 & 84.28 & & & 35.43 & \\
\hline
\end{tabular}

* Number of cells with laggards/total cells examined.

Table 4. Pollen viability and seed fertility in interspecific hybrids of Tagetes patula and T. erecta

\begin{tabular}{lccc}
\hline \multicolumn{1}{c}{ Cultivar } & $\begin{array}{c}\text { Pollen* viability } \\
(\%)\end{array}$ & $\begin{array}{c}\text { No. of viable pollen } \\
\text { per } 100\end{array}$ & $\begin{array}{c}\text { Seed fertility } \\
(\%)\end{array}$ \\
\hline Red and Gold hybrid & 14.73 & $7-23$ & 15.00 \\
Gold Nugget & 12.46 & $7-20$ & 0.00 \\
Orange Nugget & 13.62 & $4-23$ & 0.00 \\
\hline
\end{tabular}

* Mean value of three cultivates: $13.60 \%$.

\section{Discussion}

If $T$. patula $\left(\mathrm{A}_{\mathrm{p}} \mathrm{A}_{\mathrm{p}} \mathrm{B}_{\mathrm{p}} \mathrm{B}_{\mathrm{p}}\right)$ has two genomes contributed from $T$. erecta $\left(\mathrm{A}_{1} \mathrm{~A}_{1}\right)$ and the other two from a species remote to $T$. erecta, it can be assumed that in the hybrids of $T$. patula and $T$. erecta, chromosomes derived from $T$. erecta $\left(\mathrm{A}_{1}\right)$ would preferentially pair with one set of chromosomes from T. patula $\left(\mathrm{A}_{\mathrm{p}}\right)$ giving 12 bivalents, and that the remaining chromosomes from $T$. patula $\left(\mathrm{B}_{\mathrm{p}}\right)$ would be unpaired giving 12 univalents. Analysis of meiotic pairing in the hybrids showed that only about 30 percent of PMC exhibited the Drosera scheme. All cells examined had at least 6 univalents. Trivalents and quadrivalent were present in $56.95 \%$ of the PMC (Table 2). Eresen (1966) and Jalil et al. (1974) also reported 
the presence of multivalents in the triploid hybrids, but only trivalents were found. Because about 10 percent (Table 1) of the cells analyzed had more than 12 bivalents, intragenomal pairing or reciprocal translocation in the genome from the unknown parental species can be asusmed to have occurred. Bolz (1961) also observed a maximum of 15 bivalents in the speices hybrids. If $T$. erecta and $T$. tenuifolia are truly the parental species of $T$. patula, bivalents may be expected to be present in monoploids of $T$. tenuifolia as a result of intragenomal pairing or reciprocal translocation.

Colchicine induced hexaploid T. erecta-patula $\left(2 n=72, A_{1} A_{1} A_{p} A_{p} B_{p} B_{p}\right)$ were, in average, found to have 33.95 bivalents, 1.1 univalents, and only 0.75 quadrivalent per cell. No trivalents were observed (Jalil et al. 1974). Thus A genomes in $T$. erecta $\left(\mathrm{A}_{1} \mathrm{~A}_{1}\right)$ and $T$. patula $\left(\mathrm{A}_{\mathrm{p}} \mathrm{A}_{\mathrm{p}}\right)$ do not appear to correspond exactly because many more multivalents would have been expected. While absence of prevalent multivalents in a presumably polyploid species may be a result of increase in diploidization during the course of evolution (Gilles and Randolph 1951), diploidization could not be the cause for the low frequency of multivalents in this recently induced hexaploid. A low number of multivalents was also observed in induced polyploid plants of other species such as Impatiens balsamina (Raghuvanshi and Singh 1979), Zinnia elegans (Gupta and Koak 1976), Trigonella foenumgraecum L. (Rahguvanshi and Singh 1977) and Portulaca grandiflora (Singh 1979). Genetic factors (Riley and Chapman 1958, Feldman 1966) and small chromosome size could lead to a reduction in the number of multivalents. Therefore the absence of prevalent multivalents in the hexaploid $T$. erecta-patula cannot be regarded as an evidence against the proposal that $T$. patula originated from $T$. erecta.

On the other hand, $T$. jaliscensis $(2 \mathrm{n}=24)$ is thought to be an alternate source of A genomes in T. patula (Towner 1962). It would be desirable to have synthetic tetraploids from $T$. jaliscensis and $T$. tenuifolia as well as triploids between $T$. jaliscensis and $T$. patula, and its corresponding hexaploids available so that studies can be made in hope to elucidate the origin of $T$. patula.

While pollen viability of both $T$. erecta and $T$. patula were approximately $25 \%$ (Chen and Lin 1981), the hybrids had a lower viability, 13.60\%. There were at least six univalents in each PMC averaging $10.97 \pm 0.20$ per cell in the hybrids. The frequent occurrence of laggards (present in $84.29 \%$ of the PMC) can be correlated with the frequent occurrence of univalents. Physiological incompatibility and high frequency of laggards may be considered as factors contributing to the lower viability in these interspecific hybrids. Jalil et al. (1974) also reported a very low pollen viability of the triploid hybrids $(0-33 \%)$ and 0 percent of seed fertility.

The three cultivars of triploid hybrids showed similar pollen viability; but Red and Gold Hybrid exhibited 15\% seed fertility, Gold Nugget and Orange Nugget exhibited 0 percent. The differences in seed fertility were likely a result of genotypic differences among these cultivars. Intervarietal differences have been demonstrated for seed setting in some species. In ployploid Phlox drummondii, seed setting was highly variable ranging from $5 \%$ (White variety) to $95 \%$ (Yellow variety) (Raghuvanshi and Pathak 1975). 


\section{Summary}

Chromosome pairing was studied in pollen mother cells (PMC) of the interspecific hybrids $(2 n=36)$ in Tagetes patula $(2 n=48)$ and $T$. erecta $(2 n=24)$. Among the 16 configurations of chromosomal pairing observed, the configuration with 12 bivalents plus 12 univalents was most frequently seen $(30.56 \%$ of the PMC). A maximum of 15 bivalents was observed in a cell indicating some degree of intragenomal pairing in the hybrids. Trivalents and quadrivalent were present in $56.95 \%$ of the PMC, and $7.17 \%$ of the 36 chromosomes was involved in multivalent formation. In average, there were $10.97 \pm 0.20$ univalents, $11.22 \pm 0.15$ bivlants, $0.75 \pm$ 0.10 trivalent and $0.08 \pm 0.00$ quadrivalent per cell. Laggards were very frequently seen $(84.28 \%$ of the PMC). Pollen viability was $13.6 \%$ partly due to meiotic irregulatities. Seed fertility was very poor and physiological incompatibility may be considered a factor for the low fertility of the interspecific hybrids. The origin of $T$. patula is discussed.

\section{References}

Bolz, G. 1961. Genetisch-züchterische Untersuchungen bei Tagetes III. Artkrezungen in der Gattung Tagetes L. Z. Pflanzenzüchtung 46: 169-211.

Chen, J. F. and Lin, Y. J. 1981. Meiotic multivalents in Tagetes erecta and T. patula. Caryologia 34: $107-116$.

Eresen, H. 1966. Die Verwendung von künstlichen Artbastarden-insbesondere Additionsbastarden-in der Züchtung von Tagetes L. Z. Pflanzenzüchtung 56: 201-250.

Eyster, W. H. 1941. The production of polyploid Tagetes. Proc. Pennsyl. Acad. Sci. 15: 209213.

Feldman, M. 1966. The effect of chromosomes 5B, 5D and 5A on chromosomal pairing in Triticum aestivum. Proc. Nat. Acad. Sci. 55: 1447-1453.

Gilles, A. and Randolph. L. F. 1951. Reduction of quadrivalent frequency in autotetraploid maize during a period of 10 years. Am. J. Bot. 38: 12-17.

Gupta, P. K. and Koak, R. 1976. Induced autotetraploidy in Zinnia elegans Jacq. Cytologia 41: 187-191.

Jalil, R., Khoshoo, T. N. and Pal, M. 1974. Origin, nature and limit of polyploidy in marigolds. Current Science (Calcutta) 43: 777-779.

Raghuvanshi, S. S. and Pathak, C. S. 1975. Polyploid breeding and possibility of raising double varieties on Phlox drummondii Hook. Cytologia 40:355-363.

- and Singh, A. K. 1977. Polyploid breeding in Trigonella foenum-graecum L. Cytologia 42: 5-19.

- and Singh, D. N. 1979. Comparative ploidy response of different varieties of Impatients balsamina L. Cytologia 44: 241-247.

Riley, R. and Chapman, V. 1958. Genetic control of the cytologically diploid behavior of hexaploid wheat. Nature 182: 713-715.

Singh, A. K. 1979. Polyploid breeding in Portulaca grandifora L. Cytologia 44: 167-174.

Towner, J. W. 1961. Cytogenetic studies on the origin of Tagetes patula. I. Meiosis and morphology of diploid and allotetraploid $T$. erecta $\times T$. tenuifolia. Am. J. Bot. 48: 743751.

- 1962. Cytogenetics of Tagetes jaliscensis $\times$ T. erecta. Am. J. Bot. 49: 1064-1067. 